\title{
Effect of Growth Media, Starter N and P Fertilizers on Growth and Yield of Tomato under Rainfed Condition in the Central Rift Valley of Ethiopia
}

\author{
Edossa Etissa $^{1^{*}}$, Nigussie Dechassa $^{2}$ and Yibekal Alemayhu ${ }^{2}$ \\ ${ }^{1}$ Ethiopian Institute of Agricultural Research, Addis Ababa, Ethiopia \\ ${ }^{2}$ Haramaya University, Dire Dawa, Ethiopa
}

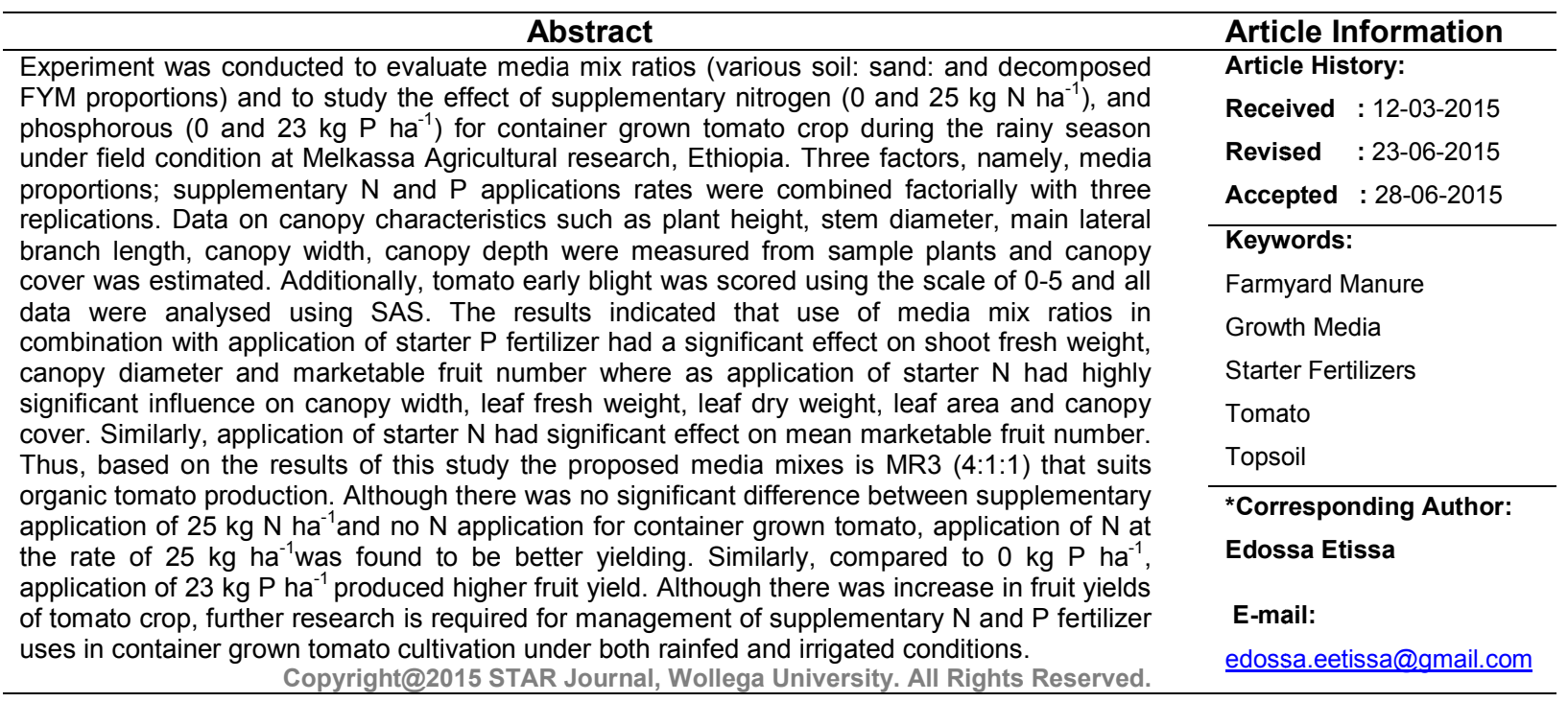

\section{INTRODUCTION}

Tomato is grown in media ranging from soil in the field, under homestead gardens, under greenhouses in potted media or nutrient solutions or hydroponics (Peet and Welles, 2005; Jones, 2008). It is clear that if tomato is grown in containers or in hydroponics conditions, all essential nutrients are required. Tomato growers in the Central Rift Valley of Ethiopia use various rates of Urea and DAP (Edossa et al., 2013b). For container grown tomatoes, it is important to select best media mixes from locally available cheap materials that provide better growth, development and fruit yield. Beside media mix ratios, $\mathrm{N}$ and $\mathrm{P}$ nutrient amendments are important as starter nutrients in tomato production (Jones, 2008).

Growing tomatoes in containers is very common and many gardeners want to grow just a few tomato plants in a pot or other container like plastic structures, and fertilizer sacks are common in urban and around preurban areas like Adama city, Ethiopia. There are many media mixtures and container designs available in the markets in other parts of the world for tomato cultivation (Heuvelink, 2005; Jones, 2008). Increased tomato production per unit of greenhouse space through the application of improved technology (automation and hydroponic culture) through cultivar development and control of the greenhouse environment has been considerable in the past years. Different researchers considered various soil mix recipes depending on its availability. Teshome et al. (2010), found that tomato seedling raised on mixed red ash, coarse sand, termite tomb and fermented cow dung in the ratio of $4: 3: 2: 1$ (in the proportion of 4 part red ash, 3 part coarse sand: 2 part termite mound, one part fermented cow dung), at Adami Tullu Research Centre in the CRV of Ethiopia resulted in the production of the highest marketable fruit yield compared to the stunted plants grown in a sole soil medium (control).

In the present scenario of continuous demand of vegetables and shrinking land holding, protected cultivation or greenhouse technology, home garden and front door cultivation are a better alternative for using land and other resources more efficiently; different researchers gave various soil mix recipes depending on the availability. A supplementary pot experiment in green house to test the response of tomato to $\mathrm{N}$ and $\mathrm{P}$ 


\section{Edossa Etissa et alo,}

application conducted at Melkassa Research Centre in a greenhouse (using the same $\mathrm{N}$ and $\mathrm{P}$ levels with the sole top $30 \mathrm{~cm}$ soil depth) was not successful. This was mainly due to soil sealing and crusting problem in a container caused by frequent irrigation water using a plastic bucket. There are many published (Itanna, 2005) and unpublished reports that soils around Melkassa (in the CRV area) usually form sealing and crusting after rainfall and furrow irrigations.

Many authors such as Singer (2006) and Shainberg (1992) explained that sealing and crusting are soil surface conditions and it is sign of physically degraded soils. These authors described that seals and crusts have higher density, higher shear strength, finer pore size distribution, and lower saturated hydraulic conductivity than uncrusted soils (Shainberg, 1992). Similarly, Itanna (2005) described that surface crusting and hardpan formation of the soils of CRV areas are the obvious symptoms of the land degradation. Many explained that these crusts and seals have greatly reduced infiltration rates because of their low porosity and lack of macropores (Singer, 2006). In addition, seals and crusts have slow gas exchange and because of their high shear strength, crusts reduce emergence of fine-seeded crops. The result is a much reduced infiltration rate and increase in volume of soil splash and overland flow.

Additions of organic matters like FYM for the improvement of plant nutrients and soil structures for container grown tomatoes; proper fertilizer formulations and rates are usually applied; starter fertilizers can promote rapid root development and early plant growth of tomatoes (Kelley and Boyhan, 2010). These authors explained that starter fertilizers for tomatoes should contain a high rate of phosphorous. Similarly, Taber and Lawson (2007) described that even if a soil test indicates
Sci. Technol. Arts Res. J., April-June 2015, 4(2): 23-31

that the phosphorous level is high to very high, starter fertilizers high in $\mathrm{P}$ are often used with the Soalanaceous crops such as potatoes and tomatoes. OMAFRA (2010) also strongly suggested that application of a highphosphorous starter fertilizer during transplanting of tomato is very important; and there are various recommendations for the starter $P$ fertilizer applications depending on the weather conditions. Tomatoes are very responsive to $\mathrm{P}$ additions at pre-planting or at the time of transplanting (Taber and Lawson, 2007; Edossa, 2014; and Edossa et al., 2013a). Hence, this experiment was conducted to select suitable locally available media mixes (soil, FYM and sand combinations) for optimum tomato growth and development, and to evaluate supplementary inorganic nitrogen and phosphorous fertilizer applications required for optimum growth and development for container grown tomato crop during main rainy season under field condition at Melkassa Research Centre, Ethiopia.

\section{MATERIALS AND METHODS}

Three factors, namely, media proportions (mixes); and supplementary $\mathrm{N}$ and $\mathrm{P}$ applications rates were combined factorial.

\section{Treatments and Treatment Combinations}

The treatments consisted of two levels of $\mathrm{N}(0$ and 25 $\mathrm{kg} \mathrm{N} \mathrm{ha-1})$, two levels of $P\left(0\right.$ and $\left.23 \mathrm{~kg} \mathrm{P} \mathrm{ha}^{-1}\right)$ and six media mix ratios (Table 1 ).

\section{Factor I. Media Proportions and Mixes (V/V)}

Locally available decayed animal manure and livestock droppings were collected and mixed with sand and topsoil at various proportions (V/V) as shown in Table 1.

Table 1: Various media mixes and proportions used for tomato grown in a container under rainfed condition at Melkassa, Ethiopia

\begin{tabular}{|c|c|c|c|c|}
\hline \multirow[b]{2}{*}{ Treatment } & \multicolumn{3}{|c|}{ Proportion of media mixes ${ }^{a}$ (V/V) } & \multirow[b]{2}{*}{ Mix Ratio } \\
\hline & $\begin{array}{c}\text { Field soil } \\
\text { (forest/ top soil }\end{array}$ & $\begin{array}{l}\text { Well decomposed } \\
\text { manure }\end{array}$ & Sand & \\
\hline 1 & 100 & 0 & 0 & 6:0:0 \\
\hline 2 & 80 & 15 & 0 & $5: 1: 0$ \\
\hline 3 & 65 & 15 & 15 & $4: 1: 1$ \\
\hline 4 & 50 & 30 & 15 & $3: 2: 1$ \\
\hline 5 & 35 & 35 & 15 & $2.5: 2.5: 1$ \\
\hline 6 & 15 & 50 & 30 & $1: 3: 2$ \\
\hline
\end{tabular}

Factor II. Supplementary N Applications

$\mathbf{N}$ application: Inorganic nitrogen fertilizer at two levels:

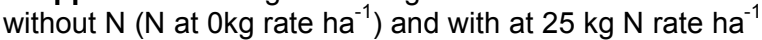
(Table 2).

\section{Factor III. Supplementary P application}

$\mathbf{P}$ application: Inorganic phosphorous fertilizer at two levels: without $\mathrm{P}$ (at $0 \mathrm{P} \mathrm{kg} \mathrm{ha-1}$ ) and with $\mathrm{P}$ at $23 \mathrm{~kg} P$ rate $\mathrm{ha}^{-1}$ (Table 2).

Table 2: Nitrogen and phosphorous fertilizer levels used with various media mixes and proportions for container grown tomato under rainfed conditions

\begin{tabular}{cccc}
\hline \multirow{2}{*}{ Levels } & \multicolumn{2}{c}{ Nitrogen and phosphorous fertilizers* } & \multirow{2}{*}{ Remakes } \\
\cline { 2 - 3 } & $\mathbf{N}$ (UREA) & $\mathbf{P}$ & \\
\hline 1 & Without $\mathrm{N}$ & Without $\mathrm{P}$ & \\
2 & $25 \mathrm{~kg} \mathrm{~N} \mathrm{ha}^{-1}$ & $23 \mathrm{~kg} \mathrm{P} \mathrm{ha}^{-1}$ & (applications of $\mathrm{P}$ once and N twice) \\
\hline
\end{tabular}

${ }^{*}=\mathrm{P}$ Fertilizers were thoroughly mixed before placing the media into the containers before transplanting, $\mathrm{N}$ were applied in two splits 


\section{Edossa Etissa et alo,}

Experimental Design: Two levels of $\mathrm{N}$ and $\mathrm{P}$ were combined to give four factorially combined $\mathrm{N}$ and $\mathrm{P}$ treatments, which were again combined with six media mix ratios giving twenty four treatment combinations. The container (pot) size used was $0.17 \mathrm{~m}^{3}$ volume. The experiment was replicated three times and 72 pots were used for each plot for the field experiment.

The experiment was laid out as a completely randomized block design in a factorial arrangement and replicated three times per treatment. The variety used was Melakshola tomato variety. The container (pot) size used was $0.17 \mathrm{~m}^{3}$ volume size. This experiment was conducted under rainfed condition during the main season. However, supplementary irrigation was provided for the containerized tomato plants during establishment in the dry spell days, and then left as a rainfed crop.

Bases for $\mathbf{N}$ and $\mathbf{P}$ Rate Determinations: Determination of $\mathrm{N}$ and $\mathrm{P}$ rates was based on plant population per ha, since these mixes were made from FYM, sand and disturbed top soil collected from the area assumed to be uncultivated for five years.

Preparation of FYM: Decayed FYM was collected from animal barren grazing natural feed and put in a pit for further decomposition and better conditions for microorganisms activity

Mixing of the Ratios: The growth media mixtures were prepared at predetermined ratios $(\mathrm{v} / \mathrm{v})$ of soil, sand and FYM; and thoroughly mixed, put for a month as a pile until filling into the pots (container) with the size of approximately $60 \mathrm{~cm}$ length and $50 \mathrm{~cm}$ wide.

\section{Determination of Physical and Chemical Properties of the Media Mixes}

Sample of FYM was analysed for the determination of the content of each essential element, namely, $\mathrm{C}, \mathrm{N}$, and $\mathrm{C}$ : $\mathrm{N}$ ratio. Additionally, some major and minor essential elements contained in the FYM, namely, $\mathrm{Na}, \mathrm{K}, \mathrm{Ca}$, available $\mathrm{P}, \mathrm{Cu}, \mathrm{Fe}, \mathrm{Mn}$ and $\mathrm{Zn}$ contents were analysed. The following general procedures and methods of routine soil analyses were made at Deber Ziet Agricultural Research Centre Soil Laboratory. These are soil reaction, $\mathrm{pH}\left(\mathrm{H}_{2} \mathrm{O}\right)$, Texture (Bouycus Hydrometer Method), ECe $\left(\mathrm{dS} \mathrm{m}{ }^{-1}\right)$ by Saturation Paste Extract Method $(1: 2.5) \mathrm{H}_{2} \mathrm{O}$, Exchangeable Cations (by neutral ammonium acetate method), CEC [( $\mathrm{cmol}_{\mathrm{c}} \mathrm{kg}^{-1}$ soil)], organic carbon (Walklay and Black, 1934); total nitrogen [Micro Kjeldshl Method, (1982)]; and available $\mathrm{P}$ ( $\mathrm{mg} \mathrm{kg}^{-1}$ soil) by using Olsen et al. (1954) methods.

Samples were taken from thoroughly mixed media for the determinations of these physical and chemical properties of the soil and availability of both macro-and micronutrients in the media mixes was determined through the analyze.

\section{Analyze of Soil Physico-chemical Properties}

Field Experiment: Seeds were sown in the nursery on 5 May 2011 and transplanting of the seedlings was done on 10 June 2011. The experiment was established in an open space during the main rainy season. Seedlings were staked immediately when it grew to the height of $60 \mathrm{~cm}$ from the ground. Supplementary irrigation was provided when there was no enough rainfall at the intervals of three to four days until sound establishment of the seedlings.
Sci. Technol. Arts Res. J., April-June 2015, 4(2): 23-31

Precautions were made to minimize the draining of nutrient solutions (leachates) since re-utilization of the drained nutrient solutions were not possible.

Data Collection and Measurement: Data on growth and canopy characteristics such as plant height, stem diameter (above the soil surface $\approx 5 \mathrm{~cm}$ ), main lateral branch length, canopy width, canopy depth $(\mathrm{cm})$ (with in row) were measured from 10 randomly selected plants per plot. Canopy cover (CC) was estimated by multiplying mean canopy width with mean canopy depth and dividing the products by the area covered by the plant (spacing between rows multiplied with spacing between plants). Additionally, tomato early blight was scored using the scale of $0-5$, where 0 indicates $=$ Freedom from disease, $1=$ indicates $10 \%$ infestation, 2 = indicates lower $10-20 \%$ infestation, $3=$ indicates middle of about $21-50 \%$ infestation, $4=$ indicates upper $51-75 \%$ infestation and finally 5 = indicates $76-90 \%$ fruit infestation (Dent, 2000). This early blight disease score was taken by senor technical assistant from MARC.

\section{RESULTS AND DISCUSSION}

\section{Physico-chemical Properties of Topsoil, Media Mix and FYM}

The physico-chemical properties of the media used for this experiment are viewed from three perspectives: nutrient content of topsoil, media mix ratios, and FYM. These are discussed separately as shown below:

\section{Nutrient Contents of Topsoil Alone}

All selected physical and chemical properties of topsoil (Check, MR1) are presented in Table 3. As compared to MR2, MR3, MR4, MR5 and MR6, the nutrient of MR1 is much lower in organic carbon (OC, very low rating) and organic matter (OM), total $\mathrm{N}, \mathrm{C}: \mathrm{N}$ ratio, available $\mathrm{P}$ and micronutrients $(\mathrm{Cu}, \mathrm{Fe}, \mathrm{Mn}$ and $\mathrm{Zn}$ ) concentrations (Table 3 ). The media MR1 (sole field soil) has very high Ca content as compared to final mixtures. The $\mathrm{Ca}$ : $\mathrm{Mg}$ balance ratio, 13.18 indicate that the top soil (MR1) was Mg deficient (Hazelton and Murphy, 2007).

\section{Nutrient Contents of Media Mixtures}

The chemical and physical properties of soil media were modified through addition of FYM and sand Although addition of FYM improved soil $\mathrm{pH}$ with small scale, the concentrations of some of the essential nutrients in the media mixtures increased; total nitrogen increased from 0.21 to $0.26 \%$, whereas available $P$ increased from 37.22 to $41.00 \mathrm{mg} \mathrm{kg}^{-1}$ (Table 3).

The amount of micronutrient concentrations were also increased manifold through addition of FYM; $\mathrm{Cu}$ increased from $0.11 \mathrm{ppm}$ to $0.34 \mathrm{ppm}$; Fe from 0.08 to $0.47 \mathrm{ppm}$; $\mathrm{Mn}$ from 7.9 to $27.00 \mathrm{ppm}$; and $\mathrm{Zn}$ from 0.708 to $3.643 \mathrm{ppm}$ (Table 3). The concentration of $\mathrm{K}$ increased five-fold from 1.93 to $9.8 \mathrm{ppm}$. The concentration of $\mathrm{Mg}$ increased more than six-fold, from 2.20 to $14.4 \mathrm{ppm}$. However, the concentration of $\mathrm{Ca}$ in the media mixture was reduced three-fold from 29.00 to $10.10 \mathrm{Cmol}(+) \mathrm{kg}^{-1}$. Addition of FYM to topsoil changed some of the chemical properties like $\mathrm{Ca}: \mathrm{Mg}$ balance ratio in various ways, improved the low Ca for MR2 (7.94) Hazelton and Murphy (2007) rating and MR3 (8.09 low Ca rating), further addition of FYM increased $\mathrm{Ca}$ : Mg ratio; MR4 (5.05 balanced rating) and MR5 (4.56 balanced), and addition of more FYM brought low Ca: Mg balance (MR6, 2.49, low Ca rating) indicating $\mathrm{Ca}$ deficient media. The ratio of high $\mathrm{Ca}$ : $\mathrm{Mg}$ as in MR1 


\section{Edossa Etissa et alo,}

indicates the presence of proportionally high $\mathrm{Ca}$ in the media, which may disrupt $\mathrm{Mg}$ uptake and vice versa.

Many researchers (Garner et al., 1930; Sims et al., 1995; Spiers and Braswell, 1994) reported that high calcium concentrations in solution or in field soils sometimes limit magnesium accumulation and may elicit magnesium deficiency symptoms). In tomato, the magnesium concentration in shoots (Gunes and Alpaslan, 1998) and fruits (Paiva et al., 1998) decreased as the calcium fertilization rate increased. Penalosa et al. (1995) also proved that increased calcium concentrations inhibited magnesium uptake in common bean (Phaseolus vulgaris L.).

Brady and Weill (2008) reported a strong antagonism between calcium and magnesium, suggesting that calcium influenced magnesium translocation to leaves. The authors suggested that optimum leaf $\mathrm{Ca}$ : $\mathrm{Mg}$ ratios are considered to be approximately $2: 1$; however, $\mathrm{Ca}$ : $\mathrm{Mg}$ ratios $>1: 1$ and $<5: 1$ can produce adequate growth without the expression of magnesium deficiency (Ericsson and Kahr, 1995; Mills and Jones, 1996).

The low $\mathrm{Ca}: \mathrm{Mg}$ balance in treatment MR6, might probably contribute to low tomato yield due to cationic balance. Handreck and Black (1999), gave the general recommendations for containerized crop production and the sufficient calcium and magnesium addition to produce an extractable Ca: $\mathrm{Mg}$ ratio of 2:5. Navarro et al. (2000) reported that there is an antagonist effect of calcium on magnesium accumulation in melon (Cucumis melo L.).

\section{Nutrient Concentration of FYM}

The average nutrient contents of FYM alone used for media mix were $0.30 \% \mathrm{~N}$, and $40.82 \mathrm{ppm}$ for $\mathrm{P}$ (Table 3 ). Very high $\mathrm{Cu}(2.39 \mathrm{ppm})$ and $\mathrm{Mn}(61.96 \mathrm{ppm})$ values were recorded; values for [10.1 $\left.\mathrm{cmol}(+) \mathrm{kg}^{-1}\right]$ were low while that of $\mathrm{Mg}\left[14.4 \mathrm{cmol}(+) \mathrm{kg}^{-1}\right]$ were high in the FYM. The animal manure can support crop growth, in particular where unbalanced $\mathrm{Ca}$ : Ma ratios exist; high content of $\mathrm{Ca}^{+2}$ can influence the uptake of $\mathrm{Mg}^{+2}$ (Hazelton and Murphy, 2007).

Due to its higher content, big losses of $\mathrm{N}$ could occur due to leaching during the heavy rain events (excess irrigation) and ammonia volatilization might occur during hot and dry conditions as hot day is very common in this CRV area. Consistent with this suggestion, Missel brook et al. (2002) reported that some fertilizers like Urea, farmyard manure, etc. may lose large amounts of nitrogen through gaseous emissions of ammonia during and after application, depending on the spreading pattern and the prevailing weather condition.

The C: $\mathrm{N}$ ratio measurement is relevant to the breakdown of organic materials in the soil and is especially applicable in discussing the effects of crop residues on soil nitrogen levels and the rate of breakdown of crop residues. Based on the analyze result, the ratings for $\mathrm{C}: \mathrm{N}$ ratio for the FYM are low (Hazelton and Murphy, 2007 ) indicating high content of nitrogen and low content of carbon; where a range from 10 to 15 are grouped somewhat as higher $\mathrm{N}$ for decomposition. However the result had shown that the $\mathrm{C}$ : $\mathrm{N}$ ratio for the check (topsoil) is low; as Hazelton and Murphy (2007) described that the $\mathrm{C}$ : $\mathrm{N}$ ratio is usually lower for soil carbon.
Sci. Technol. Arts Res. J., April-June 2015, 4(2): 23-31

Effects of Application of N, P and Media Mix Ratios on Growth, and Yield Components of Container Grown Rainfed Tomato

Analyze of variance indicated that the use of various media mixtures, application of starter $\mathrm{N}$ and $\mathrm{P}$ showed various effects on the growth characteristics, physiological responses, yield and yield components. However, combination of application of N, P and use of media mixes ratios did not affect significantly $(P<0.05$ and $P<0.01)$ any of the growth parameters assessed (Table 4 ).

Growth Characteristics: Use of media mix ratios in combination with application of starter $P$ fertilizer had a significant effect $(P<0.01)$ on some plant growth characteristics of tomato such as shoot fresh weight, canopy diameter and marketable fruit number (Table 4). Application of starter $\mathrm{N}$ had highly significant $(P<0.01)$ influence on canopy width, leaf fresh weight, leaf dry weight, leaf area and canopy cover. Similarly, application of starter $\mathrm{N}$ had significant effect $(P<0.05)$ on mean marketable fruit number per plot (Table 4$)$.

Plant Height: Application of starter N, P, use of media mix ratio or their combinations showed non-significant effect $(P<0.05)$ on tomato plant height during the rainfed season (Table 4). As compared to rainfed field grown tomato, very short plant growth (a height of $51.50 \mathrm{~cm}$ ) was recorded; this is probably due to root confinement of tomato under container growth environment. Thus, proper container size should be determined for container grown tomato in Ethiopia.

Canopy Diameter: Use of various media mix ratio had brought a significant effect $(P<0.01)$ on the canopy development of rainfed container grown tomato (Table 4). The mean separation at $P=0.05$ probability level indicated that the highest canopy diameter was recorded from MR6 while the smallest canopy size was recorded from the check (Table 4). This study indicated that combination of application of inorganic $P$ fertilizer with media mix ratios also brought a highly significant effect $(P$ $<0.01$ ) on the growth of tomato canopy diameter (Table 4 ). The relationship of use of application of starter $P$ and use of media mix ratio is presented in Figure 1 where use of MR 2, MR 3 and MR 4 with starter $P$ gave the highest fruit yield whereas use of MR 1, MR 5 and MR 6 with starter $\mathrm{P}$ gave the lowest tomato fruit yield.

Canopy Width: Use of application of starter nitrogen and media mix ratios had brought an independent and a highly significant effect $(P<0.01)$ on the canopy growth of container grown rainfed tomato (Table 4). Mean separation at $P=0.05$ probability level showed that the highest canopy width was recorded from tomato grown under media mixtures while the smallest canopy width size was recorded from the check ( Table 4).

Stem Diameter: Among tested treatments individually and in combinations, it was only media mix ratios that brought a highly significant effect $(P<0.01)$ on stem diameter (Table 4). Mean separation at $P=0.05$ probability level indicated that the highest stem diameter was recorded from media mix ratio MR6 and lowest stem diameter was recorded from the control (Table 5). 


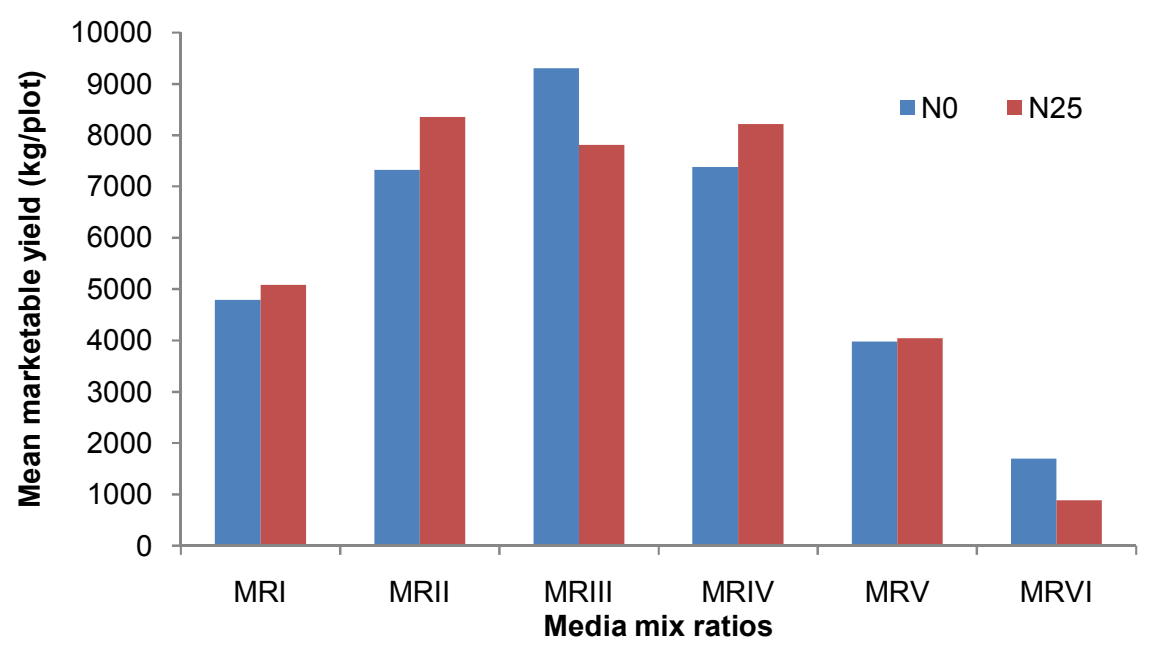

Figure 1: Average marketable fruit weight of tomato as affected by media mix ratios and application of starter $\mathrm{N}$ fertilizer

Table 3: Physico-chemical properties of different media mix ratios used for container grown rainfed tomato in comparison with FYM used for media mixing

\begin{tabular}{|c|c|c|c|c|c|c|c|c|c|c|c|c|c|c|c|}
\hline \multirow{2}{*}{$\begin{array}{c}\text { Media } \\
\text { mix } \\
\text { ratios }\end{array}$} & \multirow{2}{*}{$\begin{array}{c}\text { Soil } \\
\text { Texture }\end{array}$} & \multirow[b]{2}{*}{$\begin{array}{c}\mathrm{pH} \\
(1: 25)\end{array}$} & \multirow[b]{2}{*}{$\begin{array}{l}\text { OC } \\
(\%)\end{array}$} & \multirow[b]{2}{*}{$\begin{array}{l}\text { OM } \\
(\%)\end{array}$} & \multirow{2}{*}{$\begin{array}{c}\text { Total } \\
\mathbf{N} \\
(\%)\end{array}$} & \multirow[b]{2}{*}{$\begin{array}{c}\text { C:N } \\
\text { Ratio }\end{array}$} & \multirow{2}{*}{$\begin{array}{c}\text { Available } \\
\mathbf{P} \\
(\mathrm{ppm})\end{array}$} & \multicolumn{4}{|c|}{ Micronutrients } & \multicolumn{4}{|c|}{$\begin{array}{c}\text { Exchangeable Cations } \\
\text { cmol (+) } \mathbf{~ k g}^{-1}\end{array}$} \\
\hline & & & & & & & & $\begin{array}{c}\mathrm{Cu} \\
(\mathrm{ppm})\end{array}$ & $\begin{array}{c}\mathrm{Fe} \\
(\mathrm{ppm})\end{array}$ & $\begin{array}{c}\mathrm{Mn} \\
(\mathrm{ppm})\end{array}$ & $\begin{array}{c}\mathrm{Zn} \\
(\mathrm{ppm})\end{array}$ & $\mathrm{Na}$ & $\mathbf{K}$ & $\mathrm{Ca}$ & Mg \\
\hline $\begin{array}{c}\text { MR1 } \\
\text { (check) }\end{array}$ & Loam & 8.08 & 1.08 & 1.86 & 0.19 & 5.56 & 36,04 & 0.11 & 0.08 & 7.922 & 0.708 & 0.253 & 1.93 & 29.0 & 2.20 \\
\hline MR2 & Loam & 7.78 & 1.90 & 3.28 & 0.21 & 8.91 & 37.22 & 0.11 & 0.08 & 14.51 & 1.481 & 0.558 & 3.58 & 27.8 & 3.50 \\
\hline MR3 & $S L^{*}$ & 7.97 & 1.85 & 3.19 & 0.19 & 9.89 & 37.10 & 0.14 & 0.06 & 13.93 & 1.406 & 0.570 & 3.81 & 26.7 & 3.30 \\
\hline MR4 & $\mathrm{SL}^{*}$ & 7.95 & 3.15 & 5.43 & 0.26 & 12.00 & 38.56 & 0.17 & 0.21 & 21.85 & 2.180 & 0.889 & 6.73 & 28.8 & 5.70 \\
\hline MR5 & $S L^{*}$ & 8.03 & 3.33 & 5.74 & 0.27 & 12.16 & 36.98 & 0.30 & 0.26 & 22.30 & 2.583 & 0.856 & 6.81 & 26.5 & 5.80 \\
\hline MR6 & $\mathrm{SL}^{*}$ & 7.86 & 3.62 & 6.23 & 0.28 & 12.93 & 41.00 & 0.34 & 0.47 & 27.00 & 3.643 & 1.196 & 7.75 & 21.7 & 8.70 \\
\hline FYM & ----- & 7.91 & 3.65 & 6.03 & 0.30 & 12.17 & 40.82 & 2.39 & 0.49 & 61.96 & 3.350 & 0.122 & 9.8 & 10.1 & 14.4 \\
\hline
\end{tabular}

${ }^{*} \mathrm{SL}=$ Sandy loam texture

Table 4: Mean square values of growth characteristics, yield, yield components and physiological response of container grown tomato under different media mix ratios, $\mathrm{N}$ and $\mathrm{P}$ fertilizer applications planted under rainfed condition

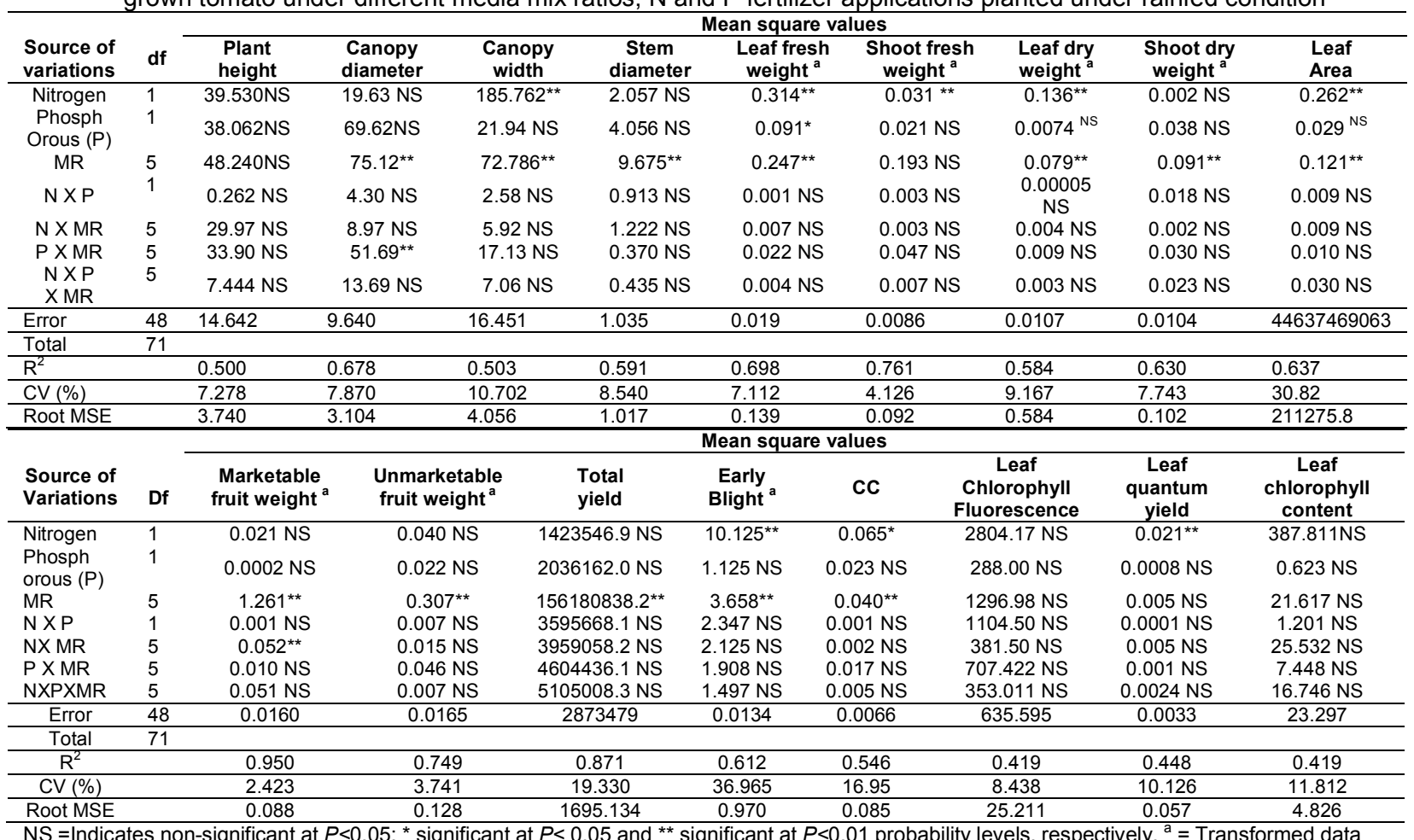


Edossa Etissa et alo,

Leaf Fresh Weight: There were no combined interaction effects $(P<0.05)$ due to the application of starter $\mathrm{N}, \mathrm{P}$, and use of media mixtures on the leaf fresh weight of tomato 'Melkasholla' variety under container grown conditions at Melkassa. On the other hand, application of starter $\mathrm{N}$ had shown a highly significant effect $(P<0.01)$ and similarly, use of media mixtures (MR) had shown a highly
Sci. Technol. Arts Res. J., April-June 2015, 4(2): 23-31

significant effect (Table 3). Mean separation at $P=0.05$ probability level showed that the highest leaf fresh weight was recorded from use of starter $\mathrm{N}$ and lowest from the check, while use of MR6 gave highest leaf fresh weight whereas the lowest was recorded from the check (Table 4).

Table 5: Mean response values of selected vegetative growth, yield components and physiological response of tomato planted under different media mixes, $\mathrm{N}$ and $\mathrm{P}$ application rates under rainfed growing conditions*

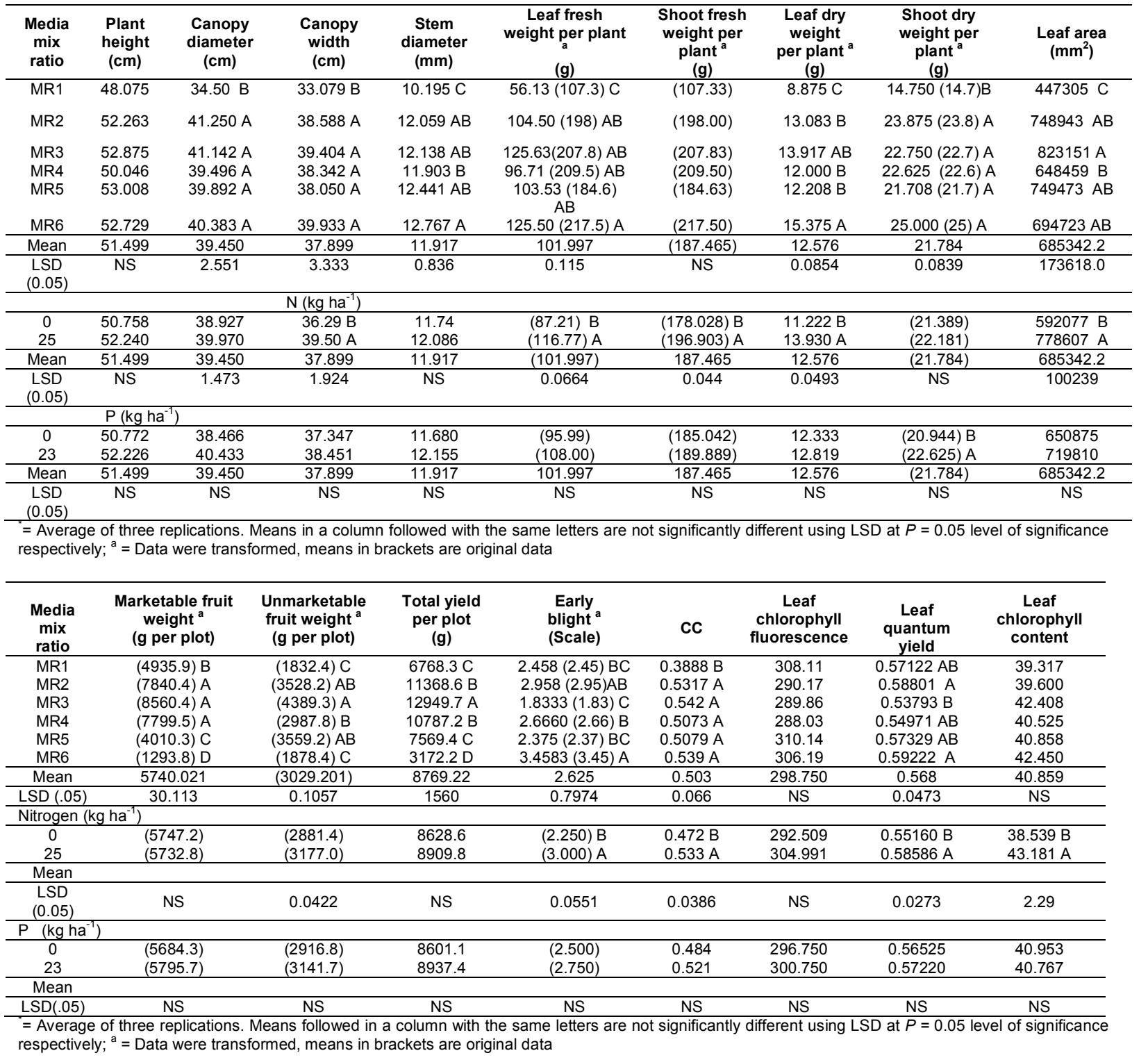

Total Shoot Fresh Weight: Among the treatments tested, there was no combined effect $(P<0.05)$ from use of starter $\mathrm{N}, \mathrm{P}$ application and media mix ratio treatments. While application of starter $\mathrm{N}$ brought a highly significant effect $(P<0.01)$ on the total shoot fresh weight. The mean separation using LSD test at $P=0.05$ probability level showed the highest shoot fresh weight use of starter $\mathrm{N}$ whereas the lowest was recorded from the check (Table 5).

Leaf Dry Weight: Use of starter $\mathrm{N}$ and various MR have shown a highly significant effect $(P<0.01)$ on the leaf dry weight of container grown tomato 'Melkasholla' variety at Melkassa. The LSD test at $P=0.05$ probability level showed that highest leaf dry weight was obtained from use of starter $\mathrm{N}$ whereas the lowest was recorded from the check. The highest leaf dry weight was obtained from use of MR 6 where as lowest was recorded from the check.

Shoot Dry Weight: Use of media mix ratios showed a highly significant effect $(P<0.01)$ on the shoot dry weight of container grown tomato at Melkassa. The LSD test at $P$ $=0.05$ probability level showed that the highest shoot dry 


\section{Edossa Etissa et alo,}

weight was obtained from those media mixtures whereas the lowest shoot dry weight was recorded from the check.

Leaf Area: Among the treatments tested, there was no combined effect $(P<0.05)$ of use of starter N, P application and media mix ratio treatments. On the other hand, application of starter $\mathrm{N}$ and use of various MR brought a highly significant effect $(P<0.01)$ independently. The LSD test at $P=0.05$ probability level indicated that the highest leaf area was obtained from using starter $\mathrm{N}$ whereas the lowest leaf area was recorded from the check. Similarly, highest leaf area was obtained from MR 3 whereas the lowest leaf area was recorded from the check. Melton and Dufault (1991) also found similar results where, as $N$ application rate increased for tomato plant from 25 to 225 $\mathrm{mg} \cdot \mathrm{liter}^{-1}$, there was as increase in the total leaf area.

Canopy Cover (CC): Use of starter $\mathrm{N}$ and media mixtures for container grown rainfed tomato at Melkassa showed a highly significant $(P<0.01)$ influence on canopy cover independently. The LSD test at $P=0.05$ probability level indicated that the highest $\mathrm{CC}$ was obtained from using starter $\mathrm{N}$ whereas the lowest leaf area was recorded from the check. Similarly, high $\mathrm{CC}$ was obtained from using media mixtures whereas the lowest leaf area was recorded from the check. Application of starter $\mathrm{P}$ alone did not have a significant effect on any of the container grown tomato plant growth parameters except shoot dry weight per plant which was significant at $P<0.05$ (Table 3 ). However, mean separation using LSD at $P=0.05$ probability level indicated that there was a trend of increasing vegetative growth parameters for those tomato plots that received starter $P$ (Table 5). Thus, further study may be required for confirmation of this result.

\section{Yield and Yield Components}

Marketable fruit yield: Use of combination of starter $\mathrm{N}$ and MR showed a significant effect $(P<0.05)$ on the marketable fruit yield of container grown tomato variety 'Melkasholla' (Table 4).

Use of media mixtures alone showed a highly significant $(P<0.01)$ effect on the marketable fruit yield of container grown tomato (Table 3 ). The LSD test at $P=$ 0.05 probability level showed that the highest marketable fruit yield was recorded from MR3, while the lowest marketable fruit yield was recorded from MR6 (Table 5). There yield increase over the grand mean of MR3 has $149.13 \%$, while MR2 has $136.58 \%$, MR6 has $135.89 \%$, MR1 has $85.98 \%$, MR5 has $69.86 \%$ and MR6 has $22.53 \%$ over the grand mean. Thus MR3 media mixture was found to be the best media mixtures produced highest tomato fruit yield. The tomato plants produced the highest marketable fruit yield in the medium that had 4:1:1 $60 \%$ soil: $15 \%$ : farmyard manure and $15 \%$ sand). The sole soil medium treatment (check) in this experiment suffered from moisture stress in the afternoons at the time of dry spells, which was disastrous during the critical growth stages prior, at and after flowering, which caused reduced growth and yield.

Total fruit yield: Use of media mix ratio showed a highly significant effect $(P<0.01)$ on the total fruit yield of container grown tomato (Table 3 ). The LSD test at $P=$ 0.05 probability level showed that MR3 yielded the highest total fruit yield while MR6 gave the lowest total fruit yield (Table 4). It is concluded from this experiment that use of the ratio of 4 field top soil: 1 manure: 1 sand order gave
Sci. Technol. Arts Res. J., April-June 2015, 4(2): 23-31

the highest fruit yield for container grown tomato around Melkassa during the rainy season; increasing the ratio of manure beyond this proportion reduced the tomato fruit yield.

Unmarketable fruit yield: Similar to marketable fruit, use of media mixtures had highly significant $(P<0.01)$ influence on the unmarketable fruit yield of container grown rainfed tomato (Table 3 ). The highest unmarketable fruit yield record was obtained from MR3 treatment while the lowest unmarketable fruit yield was obtained from the check and MR6.

Early Blight: Use of media mixtures and application of $\mathrm{N}$ had a highly significant $(P<0.01)$ effect on the occurrence of early blight of tomato (Table 3 ). Both factors affected occurrence of early blight in tomato separately. The highest blight score was recorded from MR6, and the lowest score was recorded from MR3. This probably indicates that heavy application of FYM predisposed tomato plants to the incidence of the early blight disease. This may be attributed to the increased succulence of plant leaves in response to the increased supply of nitrogen, which makes easy for the pathogen to attack and penetrate the leaves. This view is consistent with that of Barker and Bryson (2007) who reported that increased supply of nitrogen to crop plants increases susceptibility of the plants to disease. Higher score of early blight record was observed from application of $25 \mathrm{~kg} \mathrm{~N}^{-1}$ than the control treatment (Table 5).

Tomatoes grown under different media mix ratios and supplementary $\mathrm{N}$ and $\mathrm{P}$ fertilizers actually faced two major problems that limited their growth and development; one problem was root confinement and another was the intermittent moisture stress as they were grown under rainfed conditions. Tomato plants grown in field were less affected by low moisture stress during the dry spell as compared to container grown tomato; probably, field grown tomato plant roots explored more volume of soil.

Treatments with FYM were found to be less stressed during dry spells as compared to the check plot, indicating that FYM improves water holding characteristics of the media. In addition, the media containing FYM were less affected by crusting and sealing as this problem was observed in the greenhouse experiment, probably due to association with soil structure, low organic matter content of the topsoil. This is probably because farmyard manure increases organic matter content of the media, which is food for soil biota that enhance the availability of nutrients such as phosphate through increased solubilization. In addition, the organic matter holds moisture like a sponge, avoiding stress during dry days throughout the growth period of tomato plant (Muchovej et al., 2008).

\section{Correlations between Growths, Physiological Responses and Yield Components of Tomato Grown under N, P Application Rates and Media Mix Ratios}

The partial correlation analyze indicated that variables such as total fruit weight vs. leaf area, total fruit weight with marketable fruit number, total fruit weight with unmarketable fresh weight showed strong and positive correlations $\left(r^{2}\right)$. This direct relationship indicates that improving one variable improves the corresponding variable in the growth and development of container grown tomato. On the other hand, the total fruit weight with canopy diameter, total fruit weight with leaf fresh 


\section{Edossa Etissa et alo,}

weight, total fruit weight with shoot fresh weight had significant $(P<0.05)$ correlation coefficient $\left(r^{2}\right)$ (Table 6). Some other variables such as total fruit weight with plant height, canopy width and total fruit weight with stem diameter showed very weak positive associations.

Among the yield components, leaf area (LA) had strong and positive correlations with plant height $\left(r^{2}=\right.$ $\left.0.34^{\star *}\right)$, canopy diameter $\left(r^{2}=0.54^{* *}\right)$, canopy width $\left(r^{2}=\right.$
Sci. Technol. Arts Res. J., April-June 2015, 4(2): 23-31

$\left.0.64^{* *}\right)$, shoot diameter $\left(r^{2}=0.48^{* *}\right)$ and shoot fresh weight $\left(r^{2}=0.476^{\star *}\right)$. The total fruit yield showed strong and direct positive correlation with LA $\left(r^{2}=0.333^{* *}\right)$, marketable fruit number $\left(r^{2}=0.857^{\star *}\right)$, and with unmarketable fruit number $\left(r^{2}=0.74^{* *}\right)$. The results of partial correlation of physiological parameters such as leaf fluorescence, quantum yield and leaf chlorophyll content indicated that there was no direct relationship with each other and with all other parameters assessed.

Table 6: Estimation of correlation coefficient $\left(r^{2}\right)$ within and between selected growth characteristics and selected yield components for tomato as influenced by application of supplementary $\mathrm{N}, \mathrm{P}$ and various media mix ratios grown during rainy season

\begin{tabular}{|c|c|c|c|c|c|c|c|c|c|c|c|c|c|c|c|}
\hline & $\mathrm{PH}$ & CD & $\mathrm{cW}$ & SD & LFW & SFW & LA & $\mathrm{Ft}$ & QY & $\begin{array}{l}\text { Chl } \\
\text { Con }\end{array}$ & LDW & SDW & MFN & MFW & UFW \\
\hline$C D$ & $0.494^{\star \star}$ & & & & & & & & & & & & & & \\
\hline cW & $0.342^{\star *}$ & $0.690^{* *}$ & & & & & & & & & & & & & \\
\hline SD & $0.226^{\star}$ & $0.410^{\star *}$ & $0.565^{\star \star}$ & & & & & & & & & & & & \\
\hline LFW & $0.442^{\star \star}$ & $0.646^{\star \star}$ & $0.668^{\star \star}$ & $0.622^{\star \star}$ & & & & & & & & & & & \\
\hline SFW & $0.412^{* *}$ & $0.648^{\star *}$ & $0.688^{\star \star}$ & $0.613^{\star *}$ & $0.822^{* *}$ & & & & & & & & & & \\
\hline LA & $0.34^{* *}$ & $0.54^{* *}$ & $0.64^{\star *}$ & $0.48^{\star \star}$ & 0.676 & $0.476^{* *}$ & & & & & & & & & \\
\hline $\mathbf{F t}$ & 0.015 & -0.068 & 0.043 & 0.038 & 0.176 & -0.14 & 0.073 & & & & & & & & \\
\hline QY & 0.063 & 0.019 & 0.125 & 0.091 & 0.146 & -0.015 & 0.175 & 0.52 & & & & & & & \\
\hline $\begin{array}{l}\text { Chl } \\
\text { Con }\end{array}$ & 0.121 & 0.023 & 0.181 & 0.281 & $0.248^{\star}$ & 0.132 & 0.148 & -0.06 & 0.083 & & & & & & \\
\hline LDW & $0.364^{\star *}$ & $0.423^{\star \star}$ & $0.503^{\star \star}$ & $0.507^{\star \star}$ & $0.748^{\star \star}$ & $0.587^{* \star}$ & $0.473^{\star *}$ & 0.138 & 0.137 & 0.20 & & & & & \\
\hline SDW & $0.400^{\star *}$ & $0.464^{\star *}$ & $0.549^{\star *}$ & $0.515^{\star \star}$ & $0.580^{* *}$ & $0.749^{\star \star}$ & 0.21 & -0.08 & -0.06 & 0.07 & $0.469^{* *}$ & & & & \\
\hline MFN & -0.027 & 0.049 & -0.038 & -0.106 & -0.066 & 0.028 & 0.063 & -0.22 & -0.169 & -0.06 & -0.169 & -0.017 & & & \\
\hline MFW & -0.039 & 0.037 & -0.047 & -0.131 & -0.068 & -0.044 & 0.119 & -0.17 & -0.169 & -0.06 & -0.159 & -0.078 & $0.973^{\star *}$ & & \\
\hline UFW & $0.256^{*}$ & $0.412^{* *}$ & $0.328^{\star *}$ & $0.277^{\star}$ & $0.499^{* *}$ & 0.483 & 0.465 & -0.08 & -0.033 & 0.18 & 0.197 & $0.334^{* *}$ & $0.54^{* *}$ & 0.524 & \\
\hline TFW & 0.132 & $0.26^{*}$ & 0.187 & 0.070 & $0.23^{*}$ & $0.223^{*}$ & $0.333^{* *}$ & -0.15 & -0.129 & 0.05 & 0.077 & 0.149 & $0.857^{* *}$ & $0.89^{* *}$ & $0.74^{* \star}$ \\
\hline
\end{tabular}

PH: Plant height, CD: Canopy diameter, CW: Canopy width, SD: Stem diameter, LFW: Leaf fresh weight, SFW: Shoot fresh weight, LDW: Leaf dry weight, SDW: Shoot dry weight, LA: Leaf area, FMY: Fruit Marketable yield, FUY: Fruit unmarketable yield, TFY: Total fruit yield, QY: Quantum yield, ChloCon: Chlorophyll content, ChloFt: Chlorophyll Fluorescence, MFN: Marketable fruit number, MFW: Marketable fruit weight, UFN: Unmarketable fruit number UFW: Unmarketable fruit weight, TFW: Total fruit weight, ChICon: Chlorophyll content, QY: Quantum yield, Ft: Chlorophyll Fluorescence, ${ }^{a}=$ Data were transformed

\section{CONCLUSIONS}

Investigations were made to evaluate media mix ratios (various soil: sand: and decomposed FYM proportions); in the ratio of $6: 0: 0,5: 1: 0,4: 1: 1,3: 2: 1,2.5: 2.5: 1$ and1:3:2 proportions and to study the effect of supplementary inorganic nitrogen ( 0 and $25 \mathrm{~kg} \mathrm{~N}^{-1}$ ), and phosphorous ( 0 and $23 \mathrm{~kg} \mathrm{P} \mathrm{ha}^{-1}$ ) for container grown tomato crop during the rainy season under field conditions. Three factors, namely, media proportions (mixes); and supplementary $\mathrm{N}$ and $\mathrm{P}$ applications rates were combined factorially with three replications. The results indicated that among the tested six media mixes, MR3 (4:1:1) produced the highest total fruit yield, followed by MR4 $(3: 2: 1)$ in the form of field soil: manure: sand order. Since alternative fertilizer nitrogen substitution by FYM in vegetable production is commonly practiced for container grown tomato, the proposed media mixes based on the results of this study is MR3 (4:1:1) that suits organic tomato production. Use of FYM further prevented crusting and sealing of the media, which is a problem associated with top soil in the CRV area.

Although there was no significant difference between supplementary applications of $25 \mathrm{~kg} \mathrm{Nha}^{-1}$ and no $\mathrm{N}$ application for container grown tomato, application of $\mathrm{N}$ at the rate of $25 \mathrm{~kg} \mathrm{ha}^{-1}$ was found to be better yielding. Similarly, compared to $0 \mathrm{~kg} \mathrm{P} \mathrm{ha}^{-1}, 23 \mathrm{~kg} \mathrm{P}^{-1}$ produced higher fruit yield. Although there was increase in fruit yields of tomato crop, further research is required for management of supplementary $\mathrm{N}$ and $\mathrm{P}$ fertilizer uses in container grown tomato cultivation under both rainfed and irrigated conditions.

\section{Conflict of Interest}

Conflict of interest none declared

\section{REFERENCES}

Barker, A..V and Bryson, G.M. (2007). Nitrogen, pp 22-43. (In) Allen V. Barker and David J. Pilbeam (Eds). Handbook of Plant Nutrition, Taylor and Francis Group, CRC Press, New York, USA.

Brady, N.C. and Weill, R.R. (2008). Elements of the Nature and Properties of Soils: $14^{\text {th }}$ ed. Prentice-Hall, Inc., Upper Saddle River, New Jersey, USA.

Edossa Etissa (2014). Irrigation and Nutrient Management Studies on Vegetable Crops with Particular Reference to Tomato (Lycopersicum esculentum M.) in the Central Rift Valley of Ethiopia. A PhD Thesis Dissertation, School of Graduate Study, Haramaya University, Haramaya, Ethiopia, pp 310. 


\section{Edossa Etissa et al.,}

Edossa Etissa., Nigussie Dechassa., Tena Alamirew., Yibekal Alemayehu and Lemma Desalegne (2013a). Growth and Yield Components of Tomato as Influenced by Nitrogen and Phosphorous Fertilizer Applications in Different Growing Seasons. Ethiopian Journal of Agricultural Science 23: 57-77.

Edossa Etissa., Nigussie Dechassa., Tena Alamirew., Yibekal Alemayehu and Lemma Desalegne (2013b). Household Fertilizers Use and Soil Fertility Management Practices in Vegetable Crops Production: The Case of Central Rift Valley of Ethiopia. Science, Technology and Arts Research Journal 2(4): 47-55.

Ericsson, T., Kahr, M. (1995). Growth and nutrition of birch seedlings at varied relative addition rates of magnesium. Tree Physiology 15: 85-93.

Garner, W.W., McMurtrey, J.E., Jr. Bowling, J.O., Jr,. Moss E.G. (1930). Magnesium and Calcium Requirements of the Tobacco Crop. Journal of Agriculture Research 40:145-168.

Gunes, A. and Alpaslan, M.A. (1998). Critical nutrient concentrations and antagonistic and synergistic relationships among the nutrients of NFT-grown young tomato plants. Journal of Plant Nutrition 21:2035-3047.

Handreck, K.A. and. Black, N.D. (1999). Growing Media for Ornamental Plants and Turf. Sydney, Australia: University of New South Wales Press

Hazelton, P. and Murphy, B. (2007). Interpreting Soil Test Results, CSIRO Publishing, 150, Oxford Street, Collingwood VIC 3066, Australia.

Heuvelink, E. (2005). Developmental Processes, pp 53-83. (In): Ep, Heuvelink (Eds). Crop Production Science in Horticulture, Series, CAB International, CABI Publishing.

Itanna, F. (2005). Sulphur distribution in five Ethiopian Rift Valley soils under Humid and Semi- Arid Climate. Journal of Arid Environments 62(4): 597-612.

Jones J. B. Jr. (2008). Tomato Plant Culture: In the Field, Greenhouse and Home Garden, $2^{\text {nd }}$ Editions, CRC Press

Melton, R.R. and Dufault, R.J. (1991). Nitrogen, Phosphorus, and Potassium Fertility Regimes Affect Tomato Transplant Growth. Hortscience 26(2):141-142. 1991.

Mills, H.A. and Benton-Jones, J.R. (1996). Plant Analyze Handbook II. Micromacro Publishing, Athens, G. A, p. 422. National Oceanic and Atmospheric Association Climatologically Data, Annual Summary, Florida. National Climatic Data Centre, Asheville.

Misselbrook, T.H., Smith, K.A., Johnson, R.A. and Pain, B.F., 2002. Slurry Application Techniques to Reduce Ammonia Emissions: Results of some UK field-Scale experiments. Biosystems Engineering 81: 313-321.

Navarro, J.M., Matinez, V., Cerda, A. and Botella, M.A. (2000). Effect of salinity $x$ calcium interaction on cation
Sci. Technol. Arts Res. J., April-June 2015, 4(2): 23-31

balance in melon plants grown under two regimes of orthophosphate. Journal of Plant Nutrition 23(7): 9911006.

OMAFRA (2010). Tomatoes-Fertility, Excerpt from Publication 363-Vegetable Production Recommendations, Publication 363. Ontario Ministry of Agriculture, Food and Rural Affairs, Toronto, Canada, 116 pp., Date last revised, 2006, Date Accessed July 2013.

Olsen, S.R. and Sommers, L.E. (1982). Phosphorous, pp. 403-429. (In) A.L. Page (Eds). Methods of Soil Analyze, Part 2. $2^{\text {nd }}(E d$.) Amer. Soc. Agron., Madison, Wisconsin.

Paiva, E.A.S., Sampaio, R.A., Martinez, H.E.P. (1998). Composition and quality of tomato fruit cultivated in nutrient solutions containing different calcium concentrations. Journal of Plant Nutrition 21:2653-2661.

Peet, M.M. and Welles, G. (2005). Greenhouse Tomato Production. pp 257-304. In: Ep. Heuvelink (Eds). Tomatoes. CABI International. Wallingford, UK.

Penalosa, J.M., Cáceres, M.D., Sarro, M.J., (1995). Nutrition of Bean Plants in Sand Culture: Influence of calcium/ potassium ratio in the nutrient solution. Journal of Plant Nutrition 18: 2023-2032.

Shainberg, I. (1992). Chemical and mineralogical components of crusting. In: Sumner, M. E. and Stewart, B. A. (eds.) Soil Crusting Chemical and Physical Processes, pp. 33-53. Advances in Soil Science. Boca Raton, FL: Lewis Publishers.

Sims, J.L., Scholtzhauer, W.S., Grove, J.H. (1995). Soluble calcium fertilizer effects on early growth and nutrition of burley tobacco. Journal of Plant Nutrition 18(5):911-921.

Singer, M.J. (2006). Physical degradation of soils, pp 223233 (In) Giacomo Certini and Riccardo Scalenghe (Ed) Soils: Basic Concepts and Future Challenges, Cambridge University Press.

Spiers, J.M. and Braswell, J.H. (1994). Response of 'Sterling' Muscadine Grape to Calcium, Magnesium, and Nitrogen Fertilization. Journal of Plant Nutrition 17(10):1739-1750.

Taber, H.G. and Lawson, V. (2007). Starter Phosphorous Fertilizer for Tomato Production, Midwest Vegetable Production Guide for Commercial Growers 2007, www.docstoc.com/docs/51770863/Midwest-Vegetable/ Last accessed 10 June 2012).

Teshome Abdissa., Amanti Chali., Geremew Hawas and Taha Mume (2010). Effect of Seedling Management on Yield and Quality of Tomato at Adami Tullu Jiddo Kombolcha District, Central Rift Valley of Ethiopia. African Journal of Agricultural Research 5(22): 3056-3059.

Walkley, A. and Black, I.A. (1934). An examination of the Degtjareff method for determining soil organic matter and proposed modification of the chromic acid titration method. Soil Science Society of American Journal 37: 2934. 